Jernej Zupančič

\title{
Jernej Mlekuž: Abc migracij
}

\author{
Ljubljana: ZRC SAZU, 2011, 72 strani
}

$\mathrm{V}$ obilici del na temo mednarodnih selitev izstopa razmeroma drobna knjižica »ABC migracij« avtorja Jerneja Mlekuža, raziskovalca na Inštitutu za slovensko izseljenstvo ZRC SAZU. Leta 2011 jo je izdala Založba ZRC SAZU. Knjiga po naslovu obeta kratek in jedrnat kompendij, naslovnica pa prej kot to različne poglede na pojem (mednarodnih) migracij. Da je naslovnica pravzaprav bolj povedna od naslova, se bralec hitro prepriča ob listanju od A do Ž. Avtor izhaja iz osebne oziroma družinske izkušnje, pri kateri izpostavi pridobljena znanja (tuji jeziki) in izkušnje, zaradi katerih je posameznik lahko bogatejši. Avtor se v uvodnem »A je to « odreka enciklopedičnemu in leksikografskemu pristopu; noče zares učiti. Emi- oziroma imigrante naj uči življenje, opazovalec (bralec) pa naj si ob njihovih življenjskih zgodbah sam ustvari predstavo in sodbo. Avtor se torej implicitno nagiba k alternativnemu razmisleku o pojavu migracij, saj, kakor napove v začetnem poglavju, hoče bolj problematizirati kakor informirati. Ta zavestni odmik od (skoraj) utečene predstave o migracijah in migrantih postavlja v ospredje zaznavanja migranta samega, medtem ko se avtor očitno distancira od (utečene) vloge raziskovalca, ki pojasnjuje, išče, razlaga, interpretira, dvomi in konstruira. Vendar bo pozoren bralec $\mathrm{v}$ tem pristopu brez težav prepoznal zelo razširjen koncept pretežno antropološkega pristopa k raziskovanju migracij, in sicer z življenjskimi zgodbami. Ta koncept številk preprosto ne potrebuje, saj je pripovedniški v prvem in interpretativen $\mathrm{v}$ drugem delu. Zato nima smisla niti začeti razmišljati o tem, kakšno kakovost ponujajo številke (o migracijah in migrantih).

Mlekuževo delo obsega 72 strani, na katerih se poleg uvodnega »A je to« zvrsti še dvanajst kratkih (dvostranskih) poglavij - od B do Ž, od »Biti migrant« do »Ženske migracije«. Nabor je torej sledil besednemu redu in ne tematski sistematičnosti, zato že na prvi pogled - skladno z uvodno napovedanim alternativnim pristopom - deluje kot kolaž različnih opredelitev (na primer Ekonomske migracije, Ilegalne migracije, Moderne migracije ...), ki ga sem in tja prekinjajo drugače opredeljeni naslovi (na primer Od nekdaj migracije). Sam koncept poglavij je preprost: avtorjevemu kratkemu pojasnjevalnemu besedilu sledi izpoved ter sem in tja slika ali še pogosteje karikatura. Jezik je sočen in berljiv, izrazno bogat in dinamičen - kolikor je pri kratkih besedilih to sploh umestno. Citati so samo ob izpovedih, vendar na koncu ne sledi - kakor je 
običajno za monografije - poglavje s citirano literaturo. Toda ali je to glede na koncept dela sploh potrebno?

Kdo je migrant, je stvar (zelo različnih) definicij. Te postavljajo zunanji opazovalci in ne migranti. O svoji usodi (in seveda ustreznih definicijah) pogosto ne odločajo sami, pač pa okoliščine: vojne, stiske, neustrezna družbena klima ter osebna stališča in nagnjenja. Migracija je seveda predvsem izbira, tudi če (in ne tako redko, zaradi okoliščin) prisiljena. Avtor nadaljuje $\mathrm{z} »$ Ekonomsko migracijo«, ki naj bi po številu migrantov prevladovala. Ljudje se selijo zaradi boljših življenjskih priložnosti. Avtor jih imenuje »roke« in »trebuhi«. To migracijo sestavlja pisana druščina ljudi, pri katerih je mogoče ekonomske razloge selitve identificirati le kot enega izmed sprožilcev, ki so jih pognali drugam. S tem nam avtor dopoveduje, da je raznovrstno selitveno dogajanje težko zajeti v standardizirane kalupe. Ob vsej množičnosti je torej poudarjena individualnost. »Ilegalna migracija - naslednje poglavje - se posveča »ilegalcem«, osebam, ki so na skrivaj in protizakonito prestopile politične meje. Oba ilustrativna primera zadevata Slovenijo; v prvem se iz Nove Gorice v Gorico preseli Slovenka, iščoč nekaj sto metrov stran v drugi državi boljše življenje, v drugem pa po dolgih peripetijah v naši državi pristane Iranka. Tujost ilegalnih migrantov je dvojna: kulturna in politična (pravna in formalna). Povsem samosvojo dimenzijo odkriva poglavje »ezik in migracija«, v katerem avtor izpostavlja jezik kot orodje, medij, kulturo in posledico. Jezikovne spremembe so v veliki meri posledica selitvenih tokov, v katerih so selivci kljub naučenemu jeziku novega okolja ta jezik uporabljali po svoje in ga postopoma spreminjali. Jezikovno-kulturna adaptacija je implicitno dvosmerni tok, pa če puristi še tako bdijo nad jezikovno intaktnostjo. Tak primer so ZDA, kjer so zaradi angleškega vdora (in seveda sledečih selitev drugih) skoraj utihnili domači indijanski jeziki in na drugi strani Atlantika tudi irščina (gaelic), in to kljub temu, da so priseljeni Angleži v večdesetletni bilanci zanesljivo predstavljali manjšino. Toda ta ameriška angleščina je vse bolj amerikanščina in v določenih okoljih špangleščina: jasen dokaz, da je jezik posledica, ki sledi, in nikakor ne samo avantgarda narodove kulturne podobe. Za domače slovenske razmere avtor citira odstavek iz Vojnovićevih „Čefurji raus«, torej čefurščino oziroma fužinščino.

"Moderne migracije « najprej izpostavljajo trajnost selitev kot konstanto človeške vrste od homidacije do danes; tu se avtor tesno navezuje na poglavje »Od nekdaj migracije«, kjer je homo sapiens pravzaprav homo migrans - seleči se človek. Mejnik modernosti je za avtorja Kolumbov korak na Hispaniolo: dogodek, ki ga v evropski zgodovini praviloma razumemo kot ločnico med starim in novim. Toda morda je to bolj rezultat evropocentrične percepcije svetovne zgodovine kot realnost, saj so se načela življenja na drugih celinah še dolgo v veliki meri nadaljevala po tradicionalnih vzorcih in s samosvojo, prav tako nenehno se izpopolnjujočo modernizacijo. Toda Kolumbov 
korak je sprožil selitve: iskanje svobode na eni in nasilne selitve sužnjev na drugi strani. Toda kolonializem je močno pospešil oblikovanje "zahodnih « kapitalističnih družb in poevropil modernizacijo modernosti. Sedaj smo priča drugačnim tokovom, ko se v demografsko vse bolj očitni evropski vakuum, zaenkrat še ekonomsko in varnostno varen, zgrinjajo trume iskalcev dela in priložnosti, in to po različnih poteh. Sem so nekoč prihajale tudi surovine, $\mathrm{v}$ nasprotno smer pa specialisti, vojaki, avanturisti, kapital in izdelki. A to se obrača: Evropa se srečuje z neizprosno konkurenco poceni in ne dosti manj kakovostnih izdelkov iz Azije ter vse bolj tudi iz Latinske Amerike in Afrike. Migracije niso le tok ljudi, temveč tudi kapitala, blaga, idej, znanja in inovacij. Človek je kot selivec tudi posledica tega enormnega izmenjevalnega toka.

Poglavje »Novo okolje« razblinja mit o enostranski prilagodljivosti migrantov. Ti se sicer morajo znajti, privaditi, a zaradi logike življenja privajajo tudi okolje. Dvosmernost prilagoditvenih procesov je nuja, ki pa jo lahko državni sistemi bistveno zasučejo v selivcem bolj ali manj prijazne politike. Te politike do določene mere usmerjajo človeški (in posledično tudi snovni) pretok. Poti migrantov determinirajo tri glavne postavke: selitvene politike, okoliščine v ožjem in širšem časovno-prostorskem kontekstu ter (potencialni in realni) migrant sam. Zato so migracije kljub masovnosti vedno tudi individualen, tako rekoč intimen dogodek, ki človeka spremeni in kljub enkratnosti dejanja (selitve) trajno spremlja. Selitvena dejanja pa se rada ponavljajo, saj je iskanje boljšega, ne glede na to, ali to narekujejo pravno-politične okoliščine (na primer begunci, azilanti in ilegalci), ekonomske okoliščine (percipirana potreba selivca po prostorskem premiku) ali avanturizem iskanja drugačnega, trajen imperativ človeške vrste ali vsaj številnih njenih predstavnikov. Knjigo zaključuje poglavje "Ženske migracije«. Logično, ker je večina obravnavanih ilustrativnih primerov pač žensk in se povrh vsega $z \check{Z}$ numerično primerno izide ter smiselno, ker je bil ta segment $\mathrm{v}$ raziskovanju selitev pogosto nekoliko zanemarjen (danes temu sploh ni tako).

Mlekuževo delo ni sistematičen traktat o pojavu, bistvu in smislu selitev. Ni ne učbenik ne leksikon ali drug eruditski zapis, ki bi želel sistematično širiti vedenje o predmetu obravnave. Vendar lahko ta pisan, a vendar po svoje sistematično sestavljen kolaž migracijske pojavnosti marsikomu odpre številne, doslej manj poznane dimenzije selitev in selivcev ali, bolje, pogleda nanje. Seveda, tudi tako se da videti svet. Knjiga torej odpira vprašanja, terja nove (re)definicije in odkriva povezave med pojmi. Zato sploh ni lahkotno branje, in to kljub sočnim vložkom individualnih zgodb in karikatur, ki utegnejo biti bolj prepričevalne kakor dolge razprave. 